\title{
Michael G. Rossmann (1930-2019): Pioneer in crystallography of macromolecules and viruses
}

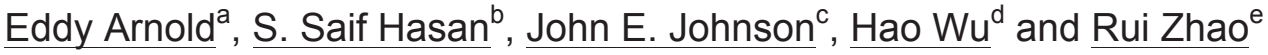 \\ ${ }^{a}$ Center for Advanced Biotechnology Medicine (CABM), Rutgers University, USA, \\ arnold@cabm.rutgers.edu \\ bUniversity of Maryland School of Medicine, USA, sshasan@som.umaryland.edu \\ 'The Scripps Research Institute, USA, jackj@scripps.edu \\ dHarvard Medical School, USA, wu@crystal.harvard.edu \\ eUniversity of Colorado, USA, Rui.Zhao@ucdenver.edu
}

Michael Rossmann was delighted to accept the ACA invitation to give an opening plenary talk at this meeting, but before having the opportunity, very sadly passed away, in West Lafayette, Indiana on May $14^{\text {th }} 2019$ (1930-2019), following a courageous five-year battle with cancer. We alumni of his research group will present memories of Michael's legacy and our interactions with him as a scientific leader, mentor and friend.

By the time of his death, Michael had been a distinguished faculty member at Purdue University for 55 years, during which he had made monumental contributions to science, and had become a towering figure in macromolecular crystallography and virology. Michael was a highly innovative and energetic individual, well known for his intensity, persistence, and focus in pursuing research goals (Figure 1).

Michael made many seminal contributions to crystallography in a career that spanned the entirety of structural biology, beginning in the 1950s at the Cavendish Laboratory in Cambridge where the first protein structures were determined by the groups of John Kendrew (myoglobin, 1958) and Max Perutz (hemoglobin, 1960). Michael worked with Perutz and was instrumental in elucidating the hemoglobin structure [1]. He wrote the computer programs required to solve and analyze these first structures, and invented methods for reliable phasing using heavy-atom isomorphous replacement and the practical determination of protein structures. During his time at Cambridge, together with David Blow, Michael also proposed and created the foundations for the molecular replacement method [2], which became the predominant approach for solving three-dimensional structures of proteins and other large biological assemblies such as complex enzymes and viruses.

After setting up his own laboratory at Purdue, Michael and his group solved the structures of several glycolytic enzymes and made the unexpected discovery that lactate dehydrogenase and glyceraldehyde-3-phosphate dehydrogenase contained a common nucleotide-binding motif, which rapidly became known as the "Rossmann Fold". Michael proposed that proteins evolve in a manner similar to the evolution of organisms and that current protein folds have diverged from common ancestors [3].

In the 1970s, Michael began to pursue his greatest scientific passion, the structure of viruses. He developed novel methods to solve the structure of a plant virus, Southern bean mosaic virus [4], followed by a common cold virus, human rhinovirus 14 [5]. These structures were especially informative in terms of the evolution of protein folds, and of biological function. Technological advances such as high-intensity synchrotron radiation and high-speed computing facilitated the determination of many RNA and DNA viruses in the following years. 
Michael was one of the early adopters of cryo-electron microscopy (cryo-EM) to analyze macromolecular structures and was prolific in producing structures of highly complex animal viruses such as dengue [6] and Zika [7] viruses, and large bacteriophages.

There are few examples of scientists who pioneer critical methods from the initial concept to full delivery of crucial results and interpretations that drive discoveries across the physical, life, and medical sciences. Michael was one such scientist, and we are deeply honored to tell his story.

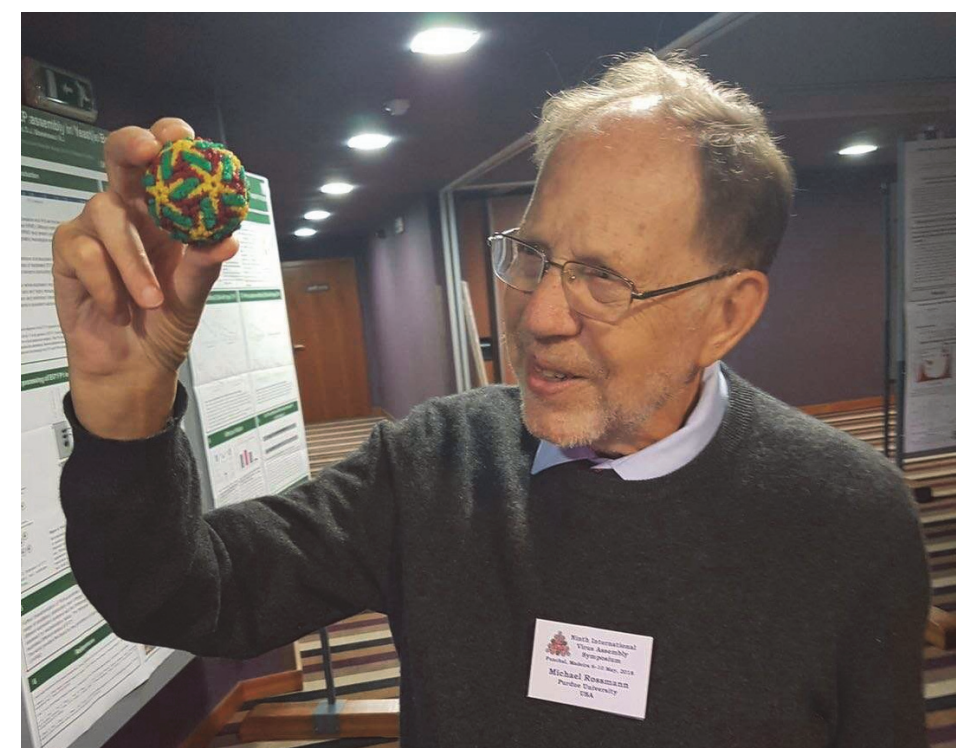

Figure 1. Michael Rossmann holding a virus model at the Ninth Virus Assembly Meeting in Madeira, Portugal, in May 2018 (photograph courtesy of Roger Castells Graells, John Innes Institute, Norwich).

\section{References}

[1] Perutz, M. F., M. G. Rossmann, A. F. Cullis, H. Muirhead, G. Will, A. C. T. North. 1960. Structure of haemoglobin. A three-dimensional Fourier synthesis at 5.5-Å resolution, obtained by X-ray analysis. Nature (London).

[2] Rossmann, M. G., D. M. Blow. 1962. The detection of sub-units within the crystallographic asymmetric unit. Acta Crystallogr. 15:24-31

[3] Rossmann, M. G., D. Moras, K. W. Olsen. 1974. Chemical and biological evolution of a nucleotide-binding protein. Nature (London) 250:194-199.

[4] Abad-Zapatero, C., S. S. Abdel-Meguid, J. E. Johnson, A. G. W. Leslie, I. Rayment, M. G. Rossmann, D. Suck, T. Tsukihara. 1980. Structure of southern bean mosaic virus at $2.8 \AA$ resolution. Nature (London) 286:33-39.

[5] Rossmann, M. G., E. Arnold, J. W. Erickson, E. A. Frankenberger, J. P. Griffith, H. J. Hecht, J. E. Johnson, G. Kamer, M. Luo, A. G. Mosser, R. R. Rueckert, B. Sherry, G. Vriend. 1985. Structure of a human common cold virus and functional relationship to other picornaviruses. Nature (London) 317:145-153.

[6] Kuhn, R. J., W. Zhang, M. G. Rossmann, S. V. Pletnev, J. Corver, E. Lenches, C. T. Jones, S. Mukhopadhyay, P. R. Chipman, E. G. Strauss, T. S. Baker, J. H. Strauss. 2002. Structure of dengue virus: implications for flavivirus organization, maturation, and fusion. Cell 108:717-725.

[7] Sirohi, D., Z. Chen, L. Sun, T. Klose, T. C. Pierson, M. G. Rossmann, R. J. Kuhn. 2016. The $3.8 \AA$ resolution cryo-EM structure of Zika virus. Science 352:467-470. 